Валентина Тасић

Филолошки факултет

Универзитет у Београду
УДК 02:004.45

дОИ https://doi.org/10.18485/

melissa.2016.15.2.ch7

\title{
БИБЛИОТЕКА „НА ДЛАНУ“: КОРИШЋЕЊЕ МОБИЛНИХ АПЛИКАЦИЈА
}

\section{Сажетак}

Технолошким напредовањем и развојем, библиотеке су успеле да прате корак са временом, а самим тим омогућиле су корисницима лакши приступ различитим информацијама. Библиотеке, као велике куће знања, постале су доступније ширем кругу корисника и данас, путем нових технологија, олакшавају и потпомажу бржем преносу информација. Употребом мобилних уређаја и преносних мини компјутера - таблета, корисник добија тражену информацију „на длану“. Иако су мобилне апликације још увек једна иновативна метода у библиотекарству, постоје тенденције да библиотека „на длану“ превазиђе постојеће библиотеке „од куће“.

Рад се даље бави опширнијом тематиком библиотеке „на длану“ и указује на њене многобројне предности. Дат је један конкретан пример на нашем подручју, где је градска библиотека у Панчеву увела мобилну апликацију под називом „Библиотека Панчево“, која је првенствено урађена за Андроид платформу. Мобилне апликације се стално развијају и омогућавају корисницима да буду обавештени „на сваком кораку“ једним додиром на екрану. На тај начин, мобилне апликације нуде библиотекама да прошире постојеће и да развију нове услуге које ће корисницима олакшати приступ траженој информацији.

Кључне речи: мобилна апликација, дигитална библиотека, дисеминација информација, „Библиотека Панчево“, корисник

\section{1. Дигиталне библиотеке}

Са напретком технологије, библиотеке су се временом преселиле у један виртуелни свет. Традиционална библиотека са километарским полицама, депоима, читаоницама, прати корак са временом и постаје доступнија ширем кругу корисника путем интернета. 
Ширењем свести да је већина корисника технолошки опремљена, библиотеке су се потрудиле да постану праве капије знања, самим тим што су пре свега постале доступне он-лајн. Путем интернет страница библиотека је корисницима омогућила приступ где год се они налазили и што је још важније, постала је досупна 24 сата дневно. У било ком тренутку, корисник може видети да ли је одређена књига доступна преко електронских каталога, шта се дешава у библиотеци (изложбе, разговори, промоције), као и да пита библиотекара за све оне информације које су му потребне. Међутим, библиотеке су отишле и корак даље, те су увеле дигиталне библиотеке, где су поставиле одређене збирке доступне свима без икакве надокнаде. Тако, данас, можете потпуно бесплатно приступити вредним колекцијама на само пар клика мишем. Дигитализацијом вредних колекција и појединих библиотечких фондова који су пре свега од културног значаја, библиотека је омогућила корисницима удаљени приступ. Напретком и развојем технологије, библиотеке су омогућиле и повезивање корисника са другим културно-научним институцијама.

На сам развој дигиталних библиотека пре свега је утицао развој интернета. Док он-лајн библиотека представља интернет страницу и једину комплетну презентацију одређене библиотеке, дигитална библиотека је искључиво дизајнирана за различите колекције које одређена библиотека поседује у својим фондовима. На тај начин, сваки корисник може приступити, читати и претраживати колекције које су раније биле доступне само директним одласком у библиотеку. Данашње библиотеке су отишле и корак даље, те су омогућиле слободан приступ свим корисницима, као и лаку размену информација како између библиотекара и корисника, тако и између самих корисника. Упоређујући данашње библиотеке са традиционалном библиотечком услугом која је укључивала интеракцију између корисника и библиотекара, у протекле две деценије, библиотечка услуга се преселила у виртуелно окружење. „Дигиталне библиотеке су увеле доста нових услуга, као што је приступ дигиталним колекцијама, веб портали, персонализоване услуге, достављање документа он-лајн, различита он-лајн упутства библиотеке, електронско издаваштво, он-лајн упутства." (Zha, Zang and Yan, 332) 
Дигитализацијом различитих колекција, библиотека је успела да прати корак ка нимало једноставним захтевима корисника. Данас, корисници могу читати, али и преузимати одређене књиге у различитим форматима који су најчешће бесплатни. И док је раније било потребно да се за одређену књигу физички дође у библиотеку, да корисник ту књигу користи искључиво у библиотеци, данас му је омогућен удаљен приступ. Како је технолошки напредак кренуо вртоглавом брзином, библиотекама је била потребна још једна новина. Путем обављених различитих истраживања, библиотеке су постале свесне да корисници пратећи технолошки развој, пре свега развој интернета, су прешли са кућних рачунара на мобилне уређаје.

\section{2. Мобилни уређаји}

Приступ различитим колекцијама, данас је омогућен не само преко кућних рачунара већ и преко мобилних уређаја. Од примене првог мобилног телефона с почетка 70-их година прошлога века, па све до данас, развој мобилних уређаја је ишао у корак са развојем рачунара. Данас, једна од најпознатијих компанија Apple, је не тако давне 2007. године, избацила на тржиште први телефон на тзв. touchscreen, односно на додир. До данас, овај телефон је прерастао у такозвани паметни телефон, где поред различитих апликација мења неколико ствари што најбоље указује на његову вишефункцијску намену у модерном добу. Како је паметни телефон постао доступнији свима, тако су и корисници библиотека кренули у претраживање информација путем мобилних уређаја. Оно на шта треба обратити посебну пажњу када се кажу мобилни уређаји јесте да ту не спадају само мобилни телефони, који су пре само деценију служили за основну комуникацију. У мобилне уређаје уврштени су и читачи електронских књига, таблети, паметни телефони као и други уређаји који се преносе и држе једном руком.

Са напретком мобилне технологије у последњих неколико година, све већи број читалаца почиње да користи библиотечке услуге и ресурсе путем различитих мобилних уређаја. Сајтови који су уређени 
искључиво за мобилне уређаје развијенији су од традиционалних веб сајтова и омогућавају корисницима да лакше превазилазе потешкоће на које наилазе путем коришћења традиционалних веб сајтова. Сведоци смо да се интернет развија из године у годину све већом брзином, те тако библиотеке пратећи овај развој прелазе и на мобилну мрежу. Већина веб сајтова има и посебно дизајнирану мобилну верзију, а чешће се данас може наићи и на мобилне апликације. Онлајн библиотеке се селе на мобилне уређаје и на тај начин постају корисницима доступније.

Традиционални веб сајтови библиотека омогућавају корисницима да приступе различитим информацијама, као и да те информације употребе на најлакши начин. Наиме, сам изглед одређене интернет странице библиотеке има поред основних информација о библиотеци, приступ електронском каталогу, али и приступ ка другим културним институцијама. И док интернет страница кориснику омогућава понекад и неорганизовани преглед информација, странице које су израђене за мобилне уређаје имају бољу прегледност. Најважнији и кључни део библиотеке на мобилним уређајима је он-лајн претраживање. „У поређењу са компилкованим садржајем традиционалне интернет странице, интерфејс интернет странице за мобилне уређаје дизајниран је јасније и садржајније, који може брзо да достави информације које корисник захтева" (Pu and Chiu, 16).

Да би се увидело колико је потребно разумети шта значи интернет презентација одређене библиотеке, односно традиционална веб страница и интернет страница на мобилним уређајима потребно је направити кратак преглед њихових разлика. Разлике приликом коришћења традиционалних веб сајтова и оних који су прилагођени мобилним уређајима су:

- Предност традиционалне верзије је та што садржи много функција. Мана је та што количина тих функција саму веб страницу чини компликованом за употребу. Сам приступ путем мобилних уређаја и икона које су обележене различитим бојама нуде прегледност тих функција и њихово лакше разликовање.

- Мобилна верзија је много лакша за употребу. Лакше се кликне на икону или алатку која је потребна самом кориснику. У 
традиционалној верзији, која није формирана за мобилне уређаје, корисници често морају да увећавају слику, што их увек доводи до неке нежељене информације јер су погрешно кликнули. Учестало увећавање формата и саме веб странице је компликовано за кориснике, те врло брзо напуштају такву интернет страницу.

Највећа мана традиционалне дигиталне библиотеке јесте та што је за одређене колекције потребна пријава односно да корисник има свој налог, како би могао да преузме одређену електронску књигу за коју је заинтересован. Већина дигиталних библиотека нуди само читање тих књига док сте он-лајн, односно не дозвољава да се књига преузме у било ком формату. На тај начин, кориснику јесте олакшан приступ самој књизи, али није у могућности да без интернета исту чита у било ком тренутку. 3бог тога је већина корисника задовољна са мобилним апликацијама.

\section{3. Мобилне апликације}

Мобилне апликације су пре свега настале са првим паметним телефоном. Данас, представљају софтверске апликације које се користе не само на мобилним телефонима, већ и на свим мобилним уређајима. Првобитно су се мобилне апликације користиле за брзу проверу електронске поште, и најчешће су се плаћале од стране корисника.

Данас, већина потребних апликација су бесплатне и омогућавају кориснику да врло лако дође до жељене информације. Данас имамо неколико категорија апликација: апликације које служе за комуникацију (електронска пошта, различите социјалне мреже), апликације за мултимедију (преглед видео и аудио датотека, преглед и обрада слика), апликације за информације (читачи вести, електронске књиге, библиотечке услуге), игрице, продуктивност (календар, роковник, планер, дигитрон, обрада текста, обрада табела) и корисне апликације (адресари, управљање датотекама).

Што се тиче библиотека ту се могу најчешће разликовати три врсте апликација: 
- Апликација за библиотечки каталог која омогућава он-лајн приступ, проверу да ли је одређена библиотечка грађа слободна и резервација исте,

- Апликација за вредне збирке односно колекције, која омогућава кориснику отворен приступ различитим колекцијама од локалног и националног значаја,

- Апликација за проширенуреалност која комбинује информације из спољног и виртуелног света односно која омогућава кориснику да потребне информације добије једноставније и прегледније него када гледа мобилну страницу одређене библиотеке.

Овом поделом апликација за библиотеке можемо видети на који начин су се оне развијале. Првенствено је за библиотеку било од велике важности да направи апликацију која ће кориснику пружити информацију о доступности њеног фонда. Данас су се ове апликације прошириле и на тај начин довеле корисника да на само пар секунди резервише одређену књигу или одређени аудио и видео запис. Буђење свести да је корисник тај који данас може врло лако заменити физичку књигу за електронску, библиотеке су морале да прате технолошки развој и самим тим да иду у корак са временом. Тако је друга подела апликације омогућила корисницима да имају отворен приступ различитим колекцијама.

На тај начин, кориснику је омогућено да са било које стране света прочита књигу која му је потребна, а да не мора физички да оде у библиотеку за коју би или било потребна међубилиотечка размена или сам физички одлазак корисника у ту удаљену библиотеку. Трећа врста апликација омогућава кориснику да у било ком тренутку види информацију како о раду саме библиотеке, тако и о културним дешавањима. Такође, ова апликција омогућава и непосредни контакт са библиотекарем који је задужен за кориснике он-лајн. Пружањем ових услуга, библиотека не само да је постала стециште знања већ и једна институција препуних информација где сваки корисник добије потребну услугу у врло кратком временском периоду.

Оно што је још употребљиво у библиотекама су такозвани QR кодови за шта је потребна још једна додатна апликација која скенира код, нпр.са слике и преноси кориснику информацију о самој књизи, кратак опис књиге као и то да ли је књига већ резервисана. 
QR кодови су настали 90-их година прошлога века, који су првенствено користили за праћење делова у производњи возила.Ови кодови раде по принципу дводимензионално, односно састављени су од вертикалних и хоризонталних линија, које заједно чине одређену информацију претварајући је у баркод. Апликације које скенирају ове кодове су најчешће увек бесплатне и оно што је важно напоменути јесте да могу бити читљиве са свих мобилних уређаја који имају камеру. Најчеше коришћење ових кодова заправо служи за одређене линкове ка сајтовима библиотека или странице друштвених мрежа, претраживање библиотечког каталога, гледање видеа или приступање музичког фајла, резервисање места у читаоници, или једноставно преузимање виртуелне туре кроз библиотеку.

У прошлости, када је корисник хтео да види одређену интернет страницу библиотеке, био му је потребан линк ка тој страници са одређени веб претраживачем. „Инсталирањем апликације, корисници данас могу веома брзо а претраже колекције књига, да читају последње вести из библотеке, да виде нову књигу месеца или дана као и да провере своје резервације односно позајмице." (Pu and Chiu, 19) Мобилне апликације су олакшале кориснику не само претраживање потребне информације већ и добијање релевантне информације, што је од изузетне важности када корисник треба ту информацију да добије у што краћем временском периоду. Све више корисника инсталира мобилне апликације како би биле у корак са библиотеком. Најчешће су то корисници млађег узраста и због тога је од велике важности да се ове апликације проширују и допуњују. Данас, корисници међусобно могу размењивати информација и на тај начин популаризовати коришћење мобилних апликација које се односе на библиотеке.

\section{4. Примери мобилних апликација у свету и код нас}

Корисници су се временом преселили потпуно у виртуелни свет, где размењујући информације међусобно, успешно добијају оне релевантне за врло кратак период. Библиотеке су својим дигиталним развојем омогућиле да иду у корак са временом и самим тим 
пребаце драгоцене фондове он лајн стварајући дигиталне библиотеке. Одређене књиге се више и не издају корисницима због њихове драгоцености и кртости. Међутим, њиховом дигитализацијом корисници су у могућности да их читају и док седе на столици, док шетају или се возе јавним превозом. Увођењем мобилних апликација, библиотеке су отвориле пут ка времеплову, али и прошириле своје досадашње услуге.

Једну од за сада најбољих библиотечких мобилних апликација нуди Њујоршка јавна библиотека. „Апликација NYPL Mobile тако садржи баркод скенер помоћу којег се у књижари може проверити да ли се одређено дело заиста налази у фонд библиотеке“. (Web 10.05.2016) Као што се и види, једна од водећих земаља где библиотеке иду у корак са временом су Сједињене Америчке Државе. Дакле, не само да корисник има могућност приступа библиотеци путем мобилног уређаја, већ може видети и да ли је одређена књига доступна уколико скенира исту у било којој књижари. На тај начин, корисник брже и лакше долази до тражене информације и не мора да чека у реду или да за потребну информацију пита библиотекара. Приликом инсталирања апликације, корисник има компетан и јасан преглед библиотечких услуга. Претражујући каталог библиотеке, корисник има опцију My library где путем свог налога може проверити шта је све позајмљивао из библиотеке. Када корисник додирне дугме поред птретраживања књига има следеће додатке: моје позајмице (где корисник види шта је до сада узимао из библиотеке), моја полица (шта се тренутно чита), као и локација (где се налази одређена књига). Поред тога корисник може читати и електронску књигу, видети шта је од нових књига пристигло у библиотеку, шта је најчешће наручивано односно коришћено и које су књиге најпродаваније. Поједине књиге корисник може преузети на мобилни уређај и читати их без интернета. Оно што је потребно нагласити јесте да су ове апликације потпуно бесплатне. Тако постоје апликације посебно за андродид платформу а посебно за iOs који је искључиво карактеристичан за Apple мобилне уређаје.

Међутим,имамо добре примере библиотечких мобилних апликација и у Европи. У Немачкој, Саксонска покрајинска библиотека као и Државна и универзитетска библиотека у Дрездену, поседују 
апликацију за баркод скенер. Такође једна од познатих апликација EconBiz којy је формирала Ценрална библиотека економских наука у Хамбургу поред функција за претраживање нуди и уживо ћаскање са библиотекаром. Ова апликација је урађена двојезично (на енглеском и немачком језику). Поред претраживања садржи ознаке за омиљене књиге и ознаку за библиотеке где корисник може видети да су ту заступљене библиотеке из Европске уније. Што се тиче претраживања, апликација нуди кориснику да може да филтрира претрагу по Буловим оператерима (AND, OR, NOT). Корисник може прегледати своју историју претраживања, тражити стручну помоћ од EconBiz-a, као и скенирати одређену књигу. Када корисник изабере књигу поред ње стоји семафор који обележава да ли је књига слободна, резвервисана или заузета. Такође корисник добија кратак опис књиге, као и то да ли је књига доступна онлајн и у ком формату. Између осталог треба напоменути и Баварску државну библиотеку која је 2010. године развила своју прву апликацију Famous Books. „Она садржи драгоцености из дигитализованог књижног фонда, међу којима се налазе уникати попут Песме о Нибелунзим која је до сада преузета 80.000 пута." (Web 10.05.2016.)

Прва библиотека у Србији која је добила своју мобилну апликацију је Градска библиотека Панчево. Ову апликацију корисници такође могу добити бесплатно првенствено за Android платформу и то преко GooglePlay продавнице. Корисници библиотеке инсталирањем ове апликације добијају основне информације о библиотеци, али и дозвољена им је претрага каталога. Треба напоменути да је апликација „Библиотека Панчево“ уведена тек 2016. године, те је још у развоју. Дакле, поред претраживања каталога (BISIS електронски каталог), апликација кориснику нуди информације о дешавањима у библиотеци, нуди листу тренутно најчитанијих књига где корисник када кликне на књигу добија и кратак опис књиге, као и опцију за писање библиотекару који је задужен за пружање информација.

Виртуелна библиотека Србије је такође добила своју мобилну апликацију mCobiss.SR. Наиме, ова апликација омогућава приступ у више од 170 библиотека широм Србије. Иначе, апликацију је ура- 
дио Институт информацијиских знаности у Марибору (Словенија) у сарадњи са Министарство образовања, науке и спорта у Словенији а све под покровитељством Европске уније. Ова апликација нуди кратко и напредно претраживање. Затим има опцију Моја библиотека где када корисник укуца назив библиотеке или место или уколико зна њен акроним изађе му број чланске карте и шифра. На тај начин корисник прегледа позајмљену грађу и овај део апликације му омогућава и продужење рока позајмице, као и преглед историје позамице и само дуговање и раздуживање књига. Такође има одељак Информације о библиотекама где може видети бројеве телефона одељења као и слање мејла библиотекарима али и њену локацију као и проналажење исте на мапи и смерница пута до те библиотеке. Такође корисник може скенирати бар код (ISBN, ISSN) са одређене књиге и на тај начин видети да ли је библиотека поседује. Једна од најзанимљивијих опција је свакако Моја полица где корисник може видети шта је тренутно узео на читање односно где може израдити списак омиљених књига. Тренутно је доступна само Андроид верзија за све мобилне уређаје. Једина мана ове апликације јесте та што ради само када је мобилни уређај повезан на интернет. Апликација је урађена двојезично односно на српском и на енглеском језику.

\section{Закључак}

Ширењем свести да је већина корисника технолошки опремљена, библиотеке су се потрудиле да постану праве капије знања, самим тим што су пре свега постале доступне он-лајн. Путем интернет страница библиотека је корисницима омогућила приступ где год се они налазили и што је још важније, постала је досупна 24 сата дневно. У било ком тренутку, корисник може видети да ли је одређена књига доступна преко електронских каталога, шта се дешава у библиотеци (изложбе, разговори, промоције), као и да пита библиотекара за све оне информације које су му потребне.

Сам рад је подељен на четири поглавља: дигиталне библиотеке (где је дат кратак опис дигиталних библиотека, њихов развој и раз- 
лика између онлајн и дигиталне библиотеке); мобилни уређаји (шта су све мобилни уређаји), треће поглавље мобилне апликације (где је дата подела и мобилних апликација које се користе у библиотекама) иа четврто поглавље су примери у свету и код нас. Дигитализацијом вредних колекција и појединих библиотечких фондова који су пре свега од културног значаја, библиотека је омогућила коринсицима удаљени приступ. Библиотечка услуга се преселила у виртуелно окружење. Први мобилни телефон направљен је с почетком 70их година прошлог века. Развој мобилних уређаја је ишао у корак са развоје рачунара. Мобилне апликације су пре свега настале са појавом првих паметних телефона. Већина мобилних апликација је бесплатна. Прегледом мобилних апликација у свету и код нас, дата је слика колико се ишло у корак са интернетом, али и колико се развијао поглед корисника библиотеке.

\section{Литература}

Xianjin Zha, Jinchao Zhang and Yalan Yan."Comparing digital libraries in the web and mobile contexts from the perspective of the digital divide". Journal of Librarianship and Information Science vol.47-4 (2015): 330-340.

Ying-Hung Pu and Po-Sheng Chiu. "The design and implementation of a Mobile Library APP System". Library Hi Tech vol.33 iss.1 (2015): 15-31.

http://www.goethe.de/ins/cs/sr/bel/kul/mag/dbs/13606591.html.-преузето 10.05.2016 


\title{
Valentina Tasic \\ University in Belgrade \\ Faculty of Philology
}

\section{LIBRARY “IN THE PALM": USE OF MOBILE APPS}

\begin{abstract}
Summary
With technological progress and development, libraries have been able to keep pace with time, and thus they enabled users to easily access a variety of information. Libraries, as big house of knowledge, have become more accessible to a wider audience, and today, through new technologies, they facilitate and support the rapid transmission of information. Using of mobile devices and portable mini computers - tablet, the user receives the requested information "in the palm". Although mobile apps are still an innovative method in librarianship, there are tendencies that the libraries "in the palm" overcome existing libraries "from home".

Further this work is dealing with the theme libraries "in the palm" and points to its numerous advantages. It was given one concrete example, in our area, where the City Library in Pancevo has introduced a mobile app called "Library of Pancevo", which is primary made for the Android platform. Mobile applications are constantly evolving and allow users to be notified "at every turn" just with one touch on the screen. In this way, mobile apps offer libraries to expand existing and develop new services that will help people to access to the requested information.
\end{abstract}

Key words: mobile application, digital library, dissemination of information, „Library of Pancevo", user 